\title{
KUALITAS ILABULO MENGGUNAKAN TEPUNG SAGU DENGAN LEVEL YANG BERBEDA
}

\author{
Nindi Nupulo, J.A.D. Kalele, S.M. Sembor, N.N. Lontaan
}

Fakultas Peternakan Universitas Sam Ratulangi Manado. 95115

\begin{abstract}
ABSTRAK
Penelitian ini bertujuan Untuk mengkaji sampai sejauh mana pengaruh tepung sagu dengan level yang berbeda terhadap kualitas makanan ilabulo makanan ilabulo. Penelitian ini dilakukan dengan menggunakan Rancangan Acak Lengkap (RAL), melalui empat perlakuan P1 (50 gram tepung sagu) P2 (100 gram tepung sagu) P3 (150 gram tepung sagu) P4 (200 gram tepung sagu) dan lima ulangan, analisis data menggunakan ANOVA (analysis of variance). Berdasarkan hasil analisis data bahwa pada variabel daya mengikat air, kadar air, aroma dan cita rasa menunjukkan perbedaan tidak nyata sedangkan pada $\mathrm{pH}$, warna dan tekstur menunjukkan perbedaan yang signifikan. Sehingga untuk semua variable maka disimpulkan bahwa penggunaan daging ayam kampung dan tepung sagu dengan takaran 100-200 gram makanan ilabulo bisa diterima oleh panelis.
\end{abstract}

Kata kunci: Ayam kampung, sagu, ilabulo

\section{ABSTRACT \\ THE QUALITY OF ILABULO USES SAGO FLOUR WITH DIFFERENT LEVELS. The study aims to evaluate the use of native chicken and starch on physical and organoleptic}

*korespondensi (corresponding author)

Email:kalelejad@unsrat.ac.id of ilabulo foods. This study was conducted using a complete random design (CRD), with four treatments: p1 (50 grams) p2 (100 grams) p3 (150 grams) p4 (200 grams) and five replication. Data was analyzed using anova (analysis of variance). Based on the results of data analysis that the variable of water holding capacity, moisture, flavor and taste showed non-significant differences while $\mathrm{pH}$, the color, texture showed significant differences. It can be concluded that the use native chicken meat and sago flour of 100-200 grams to ilabulo food could be accepted by panelist.

Keywords: native chicken, sago, ilabulo

\section{PENDAHULUAN}

Setiap daerah memiliki ciri khas makanan dan pada umumnya disesuaikan dengan bahan makanan yang digunakan atau dipadukan dengan teknik memasaknya. Makanan tersebut disukai karena rasa, tekstur dan aromanya sesuai dengan seleranya. Demikian juga dengan kebiasaan makanan khas daerah umumnya tidak mudah berubah, walaupun anggota etnik bersangkutan pindah ke daerah lain salah satunya yaitu makanan tradisional Ilabulo. Makanan tersebut biasa dikonsumsi oleh masyarakat Gorontalo 
dan sudah menjadi kebiasaan untuk menyajikan makanan tersebut terutama pada acara hajatan ataupun sehari-hari.

Makanan ini merupakan Adonannya terdiri dari jeroan (ampela dan hati), dan kulit ayam yang ditambahkan telur puyuh, jeroan dan lemak sapi. Ilabulo umumnya menggunakan tepung sagu. Proses pemasakan dapat dilakukan dengan cara dikukus atau dibakar dengan arang tempurung kelapa (Harmain et al., 2017). Kandungan kalori sagu adalah sebesar 353 kkal per $100 \mathrm{~g}$ bahan (Direktorat Gizi Departemen Kesehatan RI, 1990). Angka ini tidak jauh berbeda dengan jumlah kalori beras yaitu 364 kkal per 100 gram.

Penggunaan tepung sagu pada makanan Ilabulo digunakan sebagai bahan pengisi. Tepung sagu digunakan untuk membentuk tekstur yang padat dan kompak, menstabilkan emulsi, mengikat air dan memperbaiki sifat adonan. Tepung sagu mengandung amilosa dan amilopektin yang dapat mempengaruhi daya larut dari pati sagu dan suhu gelatinisasi. Adapun kadar amilosa pada pati sagu adalah $27 \%$ dan amilopektin sebesar 73\% (Habib, 2008). Komposisi tepung sagu yang digunakan adalah kadar air $16,63 \%$, protein $0,70 \%$, lemak $0,20 \%$ dan karbohidrat $84,70 \%$ (Haryanto dan Pangloli, 2008).

Hasil wawancara yang sudah dilakukan bahwa penggunaan tepung sagu pada makanan ilabulo ini memiliki perbedaan terutama pada level sagu. Untuk penggunaan $1 \mathrm{~kg}$ ayam kampung tepung sagu yang digunakan berbeda-beda, ada yang menggunakan 2 liter, 3 liter, dan 4 liter. Perbandingan penggunaan daging ayam kampung dan level sagu pada Ilabulo menjadi menarik untuk diteliti. Pada umumnya masyarakat hanya mengonsumsi Ilabulo tetapi tidak mengetahui kandungan gizi dari produk Ilabulo tersebut. Dengan mengetahui karakteristik organoleptik dan sifat fisik produk Ilabulo diharapkan dapat memberikan informasi kepada masyarakat tentang kandungan gizi yang ada dalam produk Ilabulo. Selain itu, pengembangan produk makanan khas daerah berbahan baku tepung sagu ini sangat penting untuk keanekaragaman produk pangan dan mengurangi konsumsi beras dikalangan masyarakat.

Tujuan Untuk mengkaji sampai sejauh mana pengaruh tepung sagu dengan level yang berbeda terhadap kualitas makanan ilabulo.

Untuk itu dilakukan penelitian tentang penggunaan daging ayam kampung dan tepung sagu dengan level yang berbeda.

\section{MATERI DAN METODE} PENELITIAN 


\section{Waktu dan tempat penelitian}

Penelitian ini dilaksanakan di Laboratorium Teknologi Hasil Ternak, Fakultas Peternakan, Universitas Sam Ratulangi Manado.

\section{Materi Penelitian}

Bahan yang digunakan terdiri dari daging ayam kampung sebanyak $4 \mathrm{~kg}$ untuk masing-masing perlakuan menggunakan $200 \mathrm{~g}$ daging, tepung sagu 50 g, 100 g, 150 g, 200 g, rempah-rempah meliputi : bawang putih $80 \mathrm{~g}$, bawang merah 80 g, lada 2 g, cabai 10 buah, garam dapur 8 g, $200 \mathrm{~mL}$ santan kelapa, $200 \mathrm{~g}$ dan daun pisang 6 lembar pada setiap perlakuan. kertas whattman 41, timbangan, 2 flat kaca dengan beban $35 \mathrm{~kg}, \mathrm{pH}$ meter dan alat uji organoleptik.

\section{Metode Penelitian}

Penelitian ini menggunakan Rancangan Acak Lengkap yang terdiri dari 4 perlakuan dan 5 ulangan, yang diatur sebagai berikut:

$$
\begin{aligned}
& \mathrm{P} 1=\text { tepung sagu } 50 \text { gram } \\
& \mathrm{P} 2=\text { tepung sagu } 100 \text { gram } \\
& \mathrm{P} 3=\text { tepung sagu } 150 \text { gram } \\
& \mathrm{P} 4=\text { tepung sagu } 200 \text { gram }
\end{aligned}
$$

\section{Variabel penelitian}

\section{Daya mengikat air}

Nilai Daya Mengikat Air (DMA) ditentukan dengan metode Hamm sesuai petunjuk (Soeparno 2005). Pertama-tama letakan sampel sebanyak $0,3 \mathrm{~g}$ di atas kertas saring Whatman 41 dan kemudian letakan diantara 2 plat kaca yang diberi beban $35 \mathrm{~kg}$ selama 5 menit. Tandai dan gambar luasan area basah disekeliling kertas saring pada kertas grafik dengan pensil dan dari gambar tersebut diperoleh area basah. Kandungan air sampel (pada area basah) dapat di ukur dengan menggunakan rumus:

Area basah = Luas lingkar luar-Luas lingkar dalam

$\mathrm{MgH} 2 \mathrm{O}=\frac{\text { area basah }\left(\mathrm{cm}^{2}\right)}{0,0948}-8,0$

$\%$ Kadar air $=$

$\frac{\text { Bobot sampel awal }- \text { Bobot sampel akhir }}{\text { Bobot sampel awal }} \times 100$

$\%$ Kadar air bebas $=\frac{\mathrm{mgH} 2 \mathrm{O}}{300 \mathrm{mg}} \times 100$

Daya mengikat Air $=\%$ kadar air total $-\%$ kadar air bebas

Semakin tinggi $\mathrm{MgH}_{2} \mathrm{O}$ yang keluar maka daya mengikat airnya semakin rendah.

\section{Kadar Air}

Cawan porselin dikeringkan dalam oven selama 1 jam dengan suhu $105^{\circ} \mathrm{C}$, kemudian didinginkan dalam desikator selama 30 menit dan ditimbang. Daging ayam ditimbang sebanyak 10 gram, lalu dimasukan dalam cawan dan ditimbang. Cawan berisi sampel dikeringkan dalam oven dengan suhu $105^{\circ} \mathrm{C}$ sampai diperoleh berat yang tetap. Cawan berisi sampel didinginkan dalam desikator dan kemudian ditimbang, Ratih et al, 2015. 
Kadar air

$=\frac{\text { B. } s+\text { cawan }- \text { berat sampel }}{\text { yang sudah dikeringkan }} \times 100 \%$

\section{Nilai pH}

Sampel ditimbang sebanyak 10 gram kemudian haluskan kemudian tambahkan akuades sebanyak $20 \mathrm{ml}$, setelah itu alat $\mathrm{pH}$ meter dikalibrasi terlebih dahulu dengan menggunakan standard $\mathrm{pH}$ netral lalu dikeringkan dengan tissue kemudian elektroda tersebut dimasukan kedalam sampel dan dibaca nilai $\mathrm{pH}$ yang tertera pada layar display alat pH meter.Soeparno, (2005) Nilai pH (potensial of hidrogen) merupakan nilai keasaman suatu senyawa atau nilai hidrogen dari senyawa tersebut.Nilai $\mathrm{pH}$ daging digunakan untuk menunjukkan tingkat keasaman dan kebasaan daging.

\section{Uji Organoleptik}

Uji organoleptik atau uji sensorik merupakan metode pengukuran kualitas suatu produk berdasarkan informasi yang diterima oleh lima panca indera yakni penciuman, penglihatan, perasa, peraba, dan pendengaran (Bourne 2002). Pengujian organoleptik perlu dilakukan untuk melihat tingkat penerimaan konsumen terhadap suatu produk. Panelis yang digunakan pada penelitian ini sebanyak 40 orang dengan kategori panelis tidak terlatih.
Skala penilaian menggunakan skala numerik :

7 = sangat suka sekali

6 = sangat suka

$5=$ suka

$4=$ netral $/$ biasa

3 = tidak suka

2 = sangat tidak suka

1 = sangat tidak suka sekali

\section{Prosedur Penelitian}

Daging ayam kampung dicuci bersih kemudian dicincang. Setelah dicincang lalu ditimbang 200 gram untuk masing-masing perlakuan. Bumbu-bumbu yang digunakan dicuci bersih. Bawang putih, bawang merah, cabai, lada, garam. Masukan daging ayam, tepung sagu dan santan kedalam wadah kemudian campurkan bahan yang telah dihaluskan dicampurkan secara merata dengan adonan, setelah tercampur secara merata adonan dibungkus dengan daun pisang berbentuk persegi panjang. kemudian siapkan panci yang sudah diisi air dan panaskan air sampai mendidih, setelah air sudah mendidih adonan yang telah dibungkus masukkan kedalam panci dikukus selama 25 menit dengan suhu $100^{\circ} \mathrm{C}$. Setelah produk sudah masak diangkat. Masukan kedalam piring dan dinginkan kurang lebih 10 menit lalu dilanjutkan dengan pengujian fisik dan organoleptik. 


\section{HASIL DAN PEMBAHASAN}

\section{Pengaruh Perlakuan Terhadap Daya Mengikat Air Ilabulo}

Hasil analisis sidik ragam menunjukkan bahwa penggunaan level tepung sagu yang berbeda memberikan pengaruh tidak berbeda nyata $(\mathrm{P}>0,05)$ terhadap nilai daya mengikat air ilabulo. Rataan tertinggi pada penelitian ini terdapat pada P4 sebesar 58,67. Menurut Soeparno (2009), daya ikat air daging sekitar 20 - 60\%. Penggunaan tepung tanaman pernah disampaikan oleh Mawati et al. (2017) dalam penelitian menggunakan tepung kedelei dan mampu meningkatkan daya mengikat air pada produk daging. Ini menggambarkan bahwa perbedaan jenis tepung sebagai filler dapat mempengaruhi daya mengikat air daging.

Daya mengikat air dapat dipengaruhi oleh bangsa, proses rigormortis, temperatur, kelembaban, pelayuan, tipe dan lokasi otot, fungsi otot, pakan, lemak intramuscular dan $\mathrm{pH}$ (Kuntoro et al., 2013).

\section{Pengaruh Perlakuan Terhadap Kadar Air Ilabulo}

Hasil analisis sidik ragam menunjukkan bahwa penggunaan level tepung sagu yang berbeda memberikan pengaruh yang tidak berbeda nyata
( $P>0,05)$ terhadap nilai kadar air ilabulo. Kadar air ilabulo tepung sagu masih memenuhi syarat mutu dan keamanan pangan syarat mutu dan keamanan pangan dengan kadar air maksimal 20-60\% (BSN 2013).

Kadar air ilabulo tepung sagu tidak jauh berbeda dengan penelitian Putra et al. (2015) yang menghasilkan kadar air $56,57 \%$ pada konsentrasi penambahan karaginan $1,5 \%$ pada otak-otak daging ayam. Kadar air produk dipengaruhi oleh jumlah tepung yang ditambahkan, hal ini terjadi karena pati yang terkandung bersifat menyerap air, sehingga air yang terkandung dalam daging terserap dan mengakibatkan penurunan kadar air.

\section{Pengaruh Perlakuan Terhadap pH Ilabulo}

Hasil analisis sidik ragam menunjukkan bahwa penggunaan level tepung sagu yang berbeda memberikan pengaruh yang berbeda nyata $(\mathrm{P}<0,01)$ terhadap pH ilabulo.

Hasil Uji BNJ menunjukkan bahwa perlakuan P2 100 gram tepung sagu memberikan pengaruh yang sama terhadap perlakuan P1 50 gram dan perlakuan P3 150 gram tetapi memberikan pengaruh yang berbeda terhadap perlakuan P4 200 gram. Perlakuan P2 memberikan 
Tabel 1. Data kualitas ilabulo menggunakan daging ayam kampung dan tepung sagu dengan level yang berbeda :

\begin{tabular}{lcccc}
\hline \multirow{2}{*}{ Rataan } & \multicolumn{4}{c}{ Perlakuan } \\
\cline { 2 - 5 } & P1 & P2 & P3 & P4 \\
& 50 gram & 100 gram & 150 gram & 200 gram \\
\hline Daya Mengikat air & 56,57 & 58,62 & 52,76 & 58,67 \\
Kadar air & 65,85 & 67,00 & 64,85 & 63,03 \\
pH & $6,60^{\mathrm{a}}$ & $6,65^{\mathrm{ab}}$ & $6,55^{\mathrm{abc}}$ & $6,49^{\mathrm{bc}}$ \\
\hline
\end{tabular}

Ket: Superskrip yang berbeda pada baris yang sama menunjukkan perbedaan yang sangat nyata $(\mathrm{P}<0,01)$

pengaruh yang sama terhadap perlakuan P3 dan perlakuan P4. Perlakuan P3 memberikan pengaruh yang sama terhadap perlakuan P4. Dari hasil uji BNJ menunjukkan bahwa perlakuan P2 memiliki nilai keasaman tertinggi dari perlakuan P1, P3 dan P4. Menurut Rahman (2007), pH ilabulo merupakan salah satu indikator penerimaan terhadap produk tepung. Nilai $\mathrm{pH}$ tepung tapioka dapat mempengaruhi sifat fungsional tepung, diantaranya sifat gelatinisasi.

\section{Rataan Kualitas Organoleptik}

Data kualitas ilabulo menggunakan tepung sagu dengan level yang berbeda dapat dilihat pada Tabel 3.

\section{Pengaruh Level Sagu Terhadap Warna Ilabulo}

Hasil analisis sidik ragam menunjukan bahwa level tepung yang berbeda pada ilabulo memberikan pengaruh yang sangat nyata $(\mathrm{P}<0,01)$ terhadap warna ilabulo.
Hasil uji BNJ menunjukkan bahwa perlakuan P4 200 gram memberikan pengaruh yang sama tehadap perlakuan P3(150 gram) dan P2 100 gram tetapi memberikan pengaruh yang berbeda terhadap perlakuan P1 50 gram, Perlakuan P3 memberikan pengaruh yang sama tehadap perlakuan P2 tetapi memberikan pengaruh yang berbeda terhadap perlakuan $\mathrm{P} 1$, pelakuan $\mathrm{P} 2$ memberikan pengaruh yang berbeda terhadap perlakuan P1. Dari hasil uji $\mathrm{BNJ}$ menunjukan bahwa pelakuan P4 dan perlakuan P3 disukai oleh panelis, disukai karena warna yang coklat dan tidak pucat. Sedangkan menurut penelitian La Ega dan Lopulalan (2015), bahwa perbedaan tepung sagu berpengaruh nyata terhadap warna atau putih tepung sagu, variasi suhu pemanasan pada tepung sagu yang telah difermentasi. Menurut penelitian yang dilakukan oleh Harmain et al. (2017), yang menggunakan ikan patin dengan level tepung tulang patin A 
Tabel 2. Nilai Rataan Kualitas Ilabulo Mengggunakan Tepung Sagu Dengan Level Yang Berbeda

\begin{tabular}{ccccc}
\hline & \multicolumn{4}{c}{ Perlakuan } \\
\cline { 2 - 5 } Variabel & P1 & P2 & P3 & P4 \\
& $\mathbf{5 0 ~ G r a m ~}$ & $\mathbf{1 0 0}$ Gram & $\mathbf{1 5 0 ~ G r a m ~}$ & $\mathbf{2 0 0}$ Gram \\
\hline Warna & $3,65^{\mathrm{a}}$ & $4,40^{\mathrm{ab}}$ & $5.3^{\mathrm{b}}$ & $5,30^{\mathrm{b}}$ \\
Aroma & 4,80 & 4,88 & 5,13 & 5,15 \\
Tekstur & $5,10^{\mathrm{a}}$ & $4,25^{\mathrm{b}}$ & $4,55^{\mathrm{ab}}$ & $4,63^{\mathrm{ab}}$ \\
cita rasa & 4,65 & 4,78 & 5,03 & 5,10 \\
\hline
\end{tabular}

Ket: Superskrip yang berbeda pada baris yang sama menunjukkan perbedaan yang nyata $(\mathrm{P}<0,01)$

dan C (15:20\%) bahwa pembentukan warna pada produkilabulo daging ayam fortifikan salah satunya karena penambahan tepung sagu. Pada saat proses pemasakan dan pemanggangan ilabulo daging ayam fortifikan mengalami gelatinisasi terutama dari penambahan tepung sagu.

Warna ilabulo ayam sebelum dimasak yaitu coklat kepucatan dan sesudah dikukus menjadi coklat tua dengan menggunakan suhu $100^{\circ} \mathrm{C}$. Hal ini sejalan dengan pendapat Winarno yang mengatakan bahwa reaksi Mayllard merupakan reaksi pencoklatan non enzimatis antara gula preduksi dan gugus amin bebas dari asam amino atau protein sehingga mengakibatkan warna pada bahan pangan menjadi coklat. Lain halnya dengan pendapat Zahra et al. (2013) bahwa bahan pangan yang dimasak bukan saja menjadi matang, tetapi karena penggunaan suhu yang cukup tinggi sehingga menjadikan warna coklat tua pada bahan pangan.

\section{Pengaruh level sagu terhadap aroma Ilabulo}

Hasil analisis sidik ragam menunjukkan bahwa level tepung sagu yang berbeda memberikan pengaruh tidak berbeda nyata $(\mathrm{P}>0,05)$ terhadap aroma Ilabulo. Panelis menyukai aroma Ilabulo mulai dari perlakuan P1 50 gram sampai dengan perlakuan P4 200 gram. Namun, ada kecenderungan tingkat kesukaan panelis seiring dengan menurunnya penggunaan tingkat level sagu yang digunakan. Hal ini dikarenakan aroma khas Ilabulo semakin menurun yang disebabkan semakin berkurangnya level tepung sagu. Winarno (2008) menyatakan bahwa aroma yang ditimbulkan merupakan hasil kombinasi antara senyawa-senyawa volatil dari daging ayam yang berasal dari degradasi protein senyawa volatil seperti merkaptan, skatol, dan $\mathrm{H}_{2} \mathrm{~S}$. 
Pengaruh level sagu terhadap tekstur Ilabulo

Hasil analisis sidik ragam menunjukkan bahwa penggunaan level tepung yang berbeda memberikan pengaruh yang nyata $(\mathrm{P}<0,01)$ terhadap tekstur Ilabulo.

Hasil uji menunjukkan bahwa perlakuan P1 memberikan pengaruh yang sama tehadap perlakuan P4 gram dan P3 tetapi memberikan pengaruh yang berbeda terhadap perlakuan P2, Perlakuan P4 memberikan pengaruh yang sama tehadap perlakuan P3 dan P2, perlakuan P3 memberikan pengruh yang sama terhadap P2. Dari hasil uji bnj menunjukan bahwa pelakuan P1 dan perlakuan P4 disukai oleh panelis, disukai karna teksturnya yang halus dan juga lembut.

Menurut Kusnandar et al. (2015) kandungan tepung sagu yang terdiri dari amilosa dan amilopektin mempengaruhi sifat kelarutan dan derajat gelatinisasi tepung sagu. Dalam laporannya bahwa tepung sagu memiliki kandungan amilopektin yang cukup tinggi yaitu 87,13\%. Amilopektin pada tepung sagu yang mudah melekat dan sedikit menyerap air, mampu menstabilkan produk ilabulo daging ayam.

\section{Pengaruh Level Sagu Terhadap Cita Rasa Ilabulo}

Hasil analisis sidik ragam menunjukkan bahwa penggunaan level tepung sagu yang berbeda memberikan pengaruh tidak berbeda nyata $(\mathrm{P}>0,05)$ terhadap cita rasa Ilabulo.

Panelis menyukai cita rasa Ilabulo dari perlakuan P1 50 gram sampai dengan perlakuan P4 200 gram. Namun, ada kecenderungan tingkat kesukaan panelis terhadap cita rasa produk ilabulo meningkat seiring dengan bertambahnya penggunaan level sagu yang digunakan. Hal ini sejalan dengan penilaian cita rasa dapat dilihat dari tekstur dan penampilan warna (Hughes et al., 1997). Selanjutnya menurut De Souza et al. (2005) dalam Tinangon et al. (2014) menyatakan bahwa penggunaan rempah pada umumnya akan meningkatkan aroma dan cita rasa pada bahan pangan olahan. Menurut Joo dan Kim (2011) menyatakan flavor utama daging olahan berupa komponen-komponen volatile maupun nonvolatile berpengaruh besar terhadap penerimaan daging olahan, terutama terhadap cita rasa daging. Flavor yang ditambahkan kedalam bahan pangan baik berupa flavor alami seperti rempahrempah.

\section{KESIMPULAN}

Berdasarkan hasil analisis data dan pembahasan untuk semua variabel maka disimpulkan bahwa penggunaan daging 
ayam kampung dan tepung sagu dengan takaran 100-200 gram makanan ilabulo bisa diterima panelis.

\section{DAFTAR PUSTAKA}

Aberle, E.D., J.C. Forrest, H.B. Hendrick, M.D. Judge dan R.A. Merkel. 2001.Principles of Meat Science. W.H. Freeman and Co., San Fransisco.

Alvarado, C.S. dan McKee. 2007. Marination to improve functional properties and safety of poultry meat. J. Appl. Poult. Res. 16:113-120.

Arizona, R., E. Suryanto, dan Y. Erwanto. 2011. Pengaruh konsentrasi asap cair tempurung kenari dan lama penyimpanan terhadap kualitas kimia dan fisik daging. Buletin Peternakan. 35:50-56

Auliah, A. 2012. Formulasi kombinasi tepung sagu dan jagung pada pembuatan mie. Jurnal Chemica 13(2): 33-38

Bourne, M.C. 2002. Tekstur Makanan dan Viskositas: Konsep dan Pengukuran. London (GB): Akademic Pr

Dewayani, R.E., M.H. Natsir, dan O. Sjofjan. 2015. Pengaruh penggunaan onggok dan ampas tahu terfermentasi mix culture (Aspergillus niger dan Rhizopus oligosporus) sebagai pengganti jagung dalam pakan terhadap kualitas fisik daging ayam pedaging. Jurnal Ilmu dan Teknologi Hasil Ternak 10(1):9-17

Direktorat Gizi Departemen Kesehatan RI. 1990. Daftar Komposisi Bahan Makanan. Bharata Karya aksara, Jakarta.
Ginting, C., S. Ginting, dan I. Suhaidi. 2014. Pengaruh jumlah bubuk kunyit terhadap mutu tahu segar selama penyimpanan pada suhu ruang. J. Rekayasa Pangan dan Pert. 2(4): 52- 60

Harmain, R.M., F. Dali, Nurjanah, A.M. Jacoeb. 2017. Karakteristik organoleptik dan kimia ilabulo ikan patin fortifikan. Jurnal Pengolahan Hasil Perikanan Indonesia 20(2): 329-338.

Haryanto, P. dan B. Pangloli. 2008. Potensi Pemanfaatan Sagu. Kanisius Yogyakarta.

Hughes, E., S. Cofrades, and D. J. Troy. 1997. Effects of fat level, oat fiber and carrageenan on frankfurters formulated with 5, 12 and $30 \%$ fat. Journal Meat Sci. 45(3): 273-2810

Joo, S.T. dan D.D. Kim. 2011. Meat quality traits and control technologies. In: Joo ST, editor. Control of meat quality. Kerala (India): Reseach Signpost.p. 1-20

Koswara, S. 2011. Nilai Gizi, Pengawetan dan Pengolahan Tahu. http://www.ebookpangan.com Agustus 2012)

Kuntoro, B., R.R.A Maheswari, H. Nuraini. 2013. Mutu fisik dan mikrobiologi daging sapi asal Rumah Potong Hewan (RPH) Pekan Baru. Jurnal Peternakan 10(1): 1-8

Kusnandar, F., H.P. Hastuti, E. Syamsir. 2015. Pati resisten sagu hasil proses hidrolisis asam dan autoclavingcooling. Jurnal Teknologi dan Industri Pangan 26(1): 52-62.

La Ega dan C.G.C. Lopulalan. 2015. Modifikasi Pati Sagu Dengan Metode 
Heat Moisture Treatment. Jurnal Teknologi Pertanian 4(2).

Lawrie, R.A. 2003. Meat Science. $6^{\text {th }}$ Edit.Terjemahan. A. Parakasi dan A. Yudha. Penerbit Universitas Indonesia, Jakarta

Mawati, A., E.H.B. Sondakh, J.A.D. Kalele, dan R. Hadju. 2017. Kualitas chicken nugget yang difortifikasi dengan tepung kacang kedelai untuk peningkatan serat pangan (dietary fiber). Zootec 37(2): 464-473.

Putra, D.A.P., T.W. Agustini, I. Wijayanti. 2015. Pengaruh penambahan karagenan sebagai stabilizer terhadap karakteristik otak-otak ikan kurisi (Nemipterus nematophorus). Jurnal Pengolahan dan Bioteknologi Hasil Perikanan 4(2): 1-10

Rahman, A. M. 2007. Mempelajari Karakteristik Kimia dan Fisik Tepung Tapioka dan Mocal (Modified Cassava Flour) Sebagai Penyalut Kacang Pada Produk Kacang Salut. Skripsi. IPB. Bogor

Ratih, D.E., H. Natsir, dan O. Sjofjan. 2015. Pengaruh penggunaan onggok dan ampas tahu terfermentasi mix culture Aspergillus niger dan Rhizopus oligosporus sebagai pengganti jagung dalam pakan terhadap kualitas fisik daging ayam pedaging. Jurnal Ilmu dan Teknologi Hasil Ternak 10(1): 9-17

Soeparno. 2005. Ilmu dan Teknologi Daging, cetakan III. Gadjah Mada University Press.Yogyakarta

Steel, R. G. D. dan J. Torrie. 1995. Prinsip dan Prosedur Statistik Suatu Pendekatan Biometrik. Edisi 2.
Cetakan 2. Alih Bahasa Bambang Sumantri. Gramedia Pustaka Utama, Jakarta.

Suryana Purawisastra dan Heru Yuniati. 2010. Kandungan natrium beberapa jenis sambal kemasan serta uji tingkat penerimaannya, PGM. 33(2): 173179

Thalib, R., Deyvie Xyzquolyna, P.N. Maspeke. 2016. Substitusi tepung biji nangka (Artocapus heterophyllus) dan tepung sagu pada pembuatan Ilabulo. Prosiding Seminar Nasional. Fakultas Pertanian Unsrat. Manado.

Tinangon, R., D. Rosyidi, L. Radiati, dan Purwadi. 2014. The influence of clove addition onphysico-chemical and organoleptical characteristics of burger meat. Scholars Journal of Engineering and Technology 2(6B): 886-889

Wahyuntari, B. dan B. Zein. 2009. Studi dan Budidaya Pengolahan Sagu. IPB Press. Bogor.

Winarno, F. G. 1997. Kimia Pangan dan Gizi. Gramedia Pustaka Utama. Jakarta.

Zahra, S. L., S.B. Dwiloka dan Mulyani. 2013. Pengaruh penggunaan minyak goreng berulang terhadap perubahan nilai gizi dan mutu hedonic pada ayam goreng. Animal Agriculture Journal 2(1): 253 - 260 